\title{
LAS GENEALOGÍAS ESPURIAS DEL IMPERIO TURCO Y EL ISLAM EN LA SILVA DE VARIA LECCIÓN DE PEDRO MEXÍA Y SUS POSIBLES EFECTOS EN LA PERCEPCIÓN DE LOS MORISCOS
}

En su artículo "Speaking Christian: Orthodoxy and difference in Sixteenth-Century Spain”, Deborah Root establecía la responsabilidad de la literatura inquisitorial en la creación de la diferencia de las minorías étnicas, en concreto del grupo de los moriscos, en la España de la temprana edad moderna sin importar su grado de asimilación y aculturación. Root responsabilizaba a la Iglesia católica de la progresiva diferenciación del morisco a quien, según se aproximaba a la ortodoxia religiosa y cultural, se le levantaba proporcionalmente el listón de la aceptabilidad. Así como los moriscos gradualmente iban aminorando la diferencia con la casta dominante, primero olvidando la religión islámica, y luego sus características culturales propias, la iglesia exigía una prueba más de su aceptación del proyecto de nación cristiana para España. Cuando a finales del siglo Xvi la última diferencia que quedaba era la establecida en torno a la herencia genealógica, los moriscos quedaron definitivamente considerados como irrecuperables para la $\mathrm{fe}^{1}$.

No obstante, mucho antes de esto, en 1540, cuando todavía existían programas activos y optimistas para la "recuperación" de los moriscos para el catolicismo², Pedro Mexía publicó en su Silva

1 Deborah Root, "Speaking Christian: Orthodoxy and difference in Sixteenth-Century Spain”, Representations, Oakland, 23 (1988), 118-134.

${ }^{2}$ Las primeras prácticas de conversión se dirigían exclusivamente a modificar la práctica religiosa de los musulmanes. Véase Jesús Riosalido, "Historia del pueblo morisco", en Los moriscos: una mirada de cuatro siglos después de su expulsión, coord. F. Díaz Esteban, Edit. Actas, Madrid, 2012, p. 15. En 1553, Carlos V apremia al vicario de la diócesis de Valencia al adoctrinamiento y evangelización de los moriscos valencianos. Véase Fernando 
de varia lección unos capítulos donde ya se puede deducir la idea de la imposibilidad de la integración y asimilación de los españoles de ascendencia musulmana en el proyecto imperial cristiano en virtud de un origen indeseable. La difusión de estas ideas encontró su vehículo en el nuevo género de la miscelánea que inaugura Mexía en España con Silva de varia lección. Las obras que se encuadran dentro de este género son una especie de enciclopedia en la que cabe todo tipo de curiosidades, hallazgos científicos y, cómo no, relatos históricos. Como Mexía explicó en su Prólogo a la Silva, ésta es una serie de "capítulos de diversos propósitos, sin perseverar ni guardar orden en ellos" ${ }^{3}$ sacados de diversas y múltiples lecturas de libros escritos en su mayoría en las lenguas clásicas. Es una obra de gran erudición basada sobre todo en autoridades del mundo antiguo, la Edad Media y del Humanismo. $\mathrm{Si}$, como argumentaba Root, la Iglesia tenía el poder de formar opinión, la relevancia y éxito del autor sevillano también lo tenía. El éxito editorial de la Silva fue excepcional no sólo en España, sino en el resto de Europa, con más de ciento siete ediciones en ciento treinta años ${ }^{4}$. Tal alcance de difusión la convirtió en un vehículo enormemente eficaz para la transmisión de propaganda ideológica para un amplio público que sólo conocía su lengua vernácula. La Silva no sólo fue un gran éxito editorial durante décadas, sino que sirvió de fuente para autores del canon literario europeo como Cervantes, Montaigne, Shakespeare y Marlowe $^{5}$. Su voz fue dominante y sumamente influyente. Su pre-

Díaz Esteban, "La doble religión de los moriscos", también en ese volumen coordinado por él, p. 75. Todavía se creía en la posibilidad de ganarse a los moriscos para el cristianismo sin que cupiera en la discusión ninguna referencia a la genealogía como impedimento. Esto no quita que los moriscos no sufrieran presiones, especialmente de la Inquisición, como explica Trevor DADSON en su estudio sobre los moriscos castellanos: Los moriscos de Villarrubia de los Ojos. (Siglos XV-XVIII: historia de una minoría asimilada, expulsada y reintegrada), Iberoamericana-Vervuert, Frankfurt/M., 2007, pp. 74-83.

3 Pedro Mexía, Silva de varia lección, ed. A. Castro, Cátedra, Madrid, 1989, p. 161.

${ }^{4}$ Cf. Antonio Castro en ibid., p. 53.

${ }^{5}$ Las misceláneas no sólo sirven de referencia al público general, sino que han sido fuente de material para diversos autores que hoy consideramos canónicos en las letras renacentistas. Para la influencia en Marlowe, véase Inving Ribner, The English History play in the age of Shakespeare, Routledge, Oxon, 2005, p. 60. Para la influencia en Shakespeare, véase Gregory M. Colón Semenza, "«Second childness» and the Shakespearean vision of ideal parenting", en Gender and Early Modern constructions of childhood, eds. N. Miller \& N. Yavneh, Ashgate, Burlington, 2011, pp. 223-235. Sobre Mon- 
sentación de la realidad del mundo natural o la historia tendría que afectar la cosmovisión del siglo que le siguió en modos que necesitan ser mejor estudiados ${ }^{6}$.

En cuanto a su influencia sobre la percepción de las minorías étnico-religiosas, son de señalar estos capítulos en torno al Imperio otomano y el origen del islam, donde ya se articulan las nociones de legitimidad y ortodoxia política acerca de la noción de legitimidad genealógica. En estos capítulos se enfrenta una pretendida ilegitimidad de la aspiración imperial turca, representada en el origen cuestionable de sus emperadores, con la legitimidad del sacro Imperio romano germánico, cuya corona en esos momentos descansaba en la cabeza del futuro patrón del escritor: Carlos V, de la dinastía Habsburgo. La obsesión por la genealogía como vara de medir la legitimidad se explica por la participación de Mexía, junto con muchos otros humanistas, en las campañas de propaganda de los Habsburgo para hacer valer sus derechos a la corona imperial con argumentos genealógicos -campañas que pretendían convertir una institución tradicionalmente electiva en una hereditaria ${ }^{7}$. La otra obra magna de Mexía, Historia imperial y cesárea (1545), con la que aspiraba a ganarse el puesto de cronista imperial, que conseguiría en 1548, era en gran parte una

taigne, véase Richard Sholar, Montaigne and the art of free thinking, Peter Lang, Witney, 2010, p. 23.

${ }^{6}$ Las últimas ediciones de Silva son las de Antonio Castro, de 1988, citada supra, y la de Isaías Lerner, Silva de varia lección, Castalia, Madrid, 2003. La mayoría de las referencias al autor sevillano en trabajos académicos se limitan al establecimiento de su obra como fuente para otros autores. RichARD KAGAN más recientemente evalúa la tarea historiadora de Mexía dentro del contexto imperial (Clio and the Crown: The politics of history in medieval and early modern Spain, Johns Hopkins University Press, Baltimore, 2009).

${ }^{7}$ La idea de unidad en la cristiandad, como significado último del Imperio, auspiciada por humanistas nórdicos, especialmente Erasmo, con quien Mexía mantenía correspondencia, fue recogida por otros humanistas a sueldo de los Habsburgo. Véase Frances Yates, Astraea: The imperial theme in the sixteenth century, Routledge \& K. Paul, Boston, 1975, pp. 19 y 22-23. Tales eran los casos de Antonio de Valdés o Antonio de Guevara, a cuyo puesto de cronista real, liberado debido a su muerte, aspiraba Mexía. Las invenciones genealógicas para legitimar los derechos de los Habsburgo a la corona imperial también fueron elaboradas por humanistas de la corte imperial, especialmente durante el reinado de Maximiliano I; véase MARIE TANNER, The last descendant of Aeneas: The Hapsburgs and the mythic image of the emperor, Yale University Press, New Haven, 1993. Así pues, puede decirse que la ambición humanista de una restauración de la romanidad fue puesta al servicio del Imperio, causa en la cual Mexía participaba con su trabajo. 
obra sobre las estirpes de los detentadores de la corona imperial. En ella establecía la línea sucesoria de emperadores desde Julio César hasta Maximiliano I, abuelo de Carlos V, en una manera que contrasta con el linaje del Imperio turco según lo detalla en la Silva ${ }^{8}$.

$\mathrm{Al}$ contexto político en torno al emperador y su obsesión con la genealogía como estrategia legitimadora, hay que añadirle el hecho de que el contexto histórico social español en el que escribe Mexía se hace eco y amplifica estas articulaciones de legitimidad basadas en la genealogía. Desde el momento en que las que habían sido etnias separadas oficialmente por la religión en un sistema que puede llamarse de $\operatorname{castas}^{9}$ encuentran tal diferencia neutralizada por las conversiones masivas, forzadas o no, la sociedad española se reorganiza para seguir manteniendo los privilegios de casta medievales en torno a nociones de origen. Debido a la ausencia de diferencia física que pudiese distinguir a la mayoría de los habitantes de la Península ibérica, la diferencia se construía sobre ciertas características culturales y finalmente, para los más integrados en la cultura mayoritaria, sobre la ascendencia de los individuos y las familias ${ }^{10}$.

A pesar de que en la obra de Mexía nunca se hace referencia directa a los moriscos, los capítulos de los que se ocupa este artículo les afectarían especialmente. Por un lado, el islam fue practicado en libertad por sus antepasados, y a escondidas por algunos de ellos mismos. Por otro, el peligro de una alianza entre moriscos y turcos contra el Imperio español se blandía para avivar la ansiedad del despertar del antiguo enemigo, sobre todo cuando en las costas del Mediterráneo peninsular se temía por las incursiones de corsarios berberiscos protegidos por el Impe-

8 Pedro Mexía, Historia imperial y cesárea, Joan Oporino, Basel, 1547.

${ }^{9}$ Judíos y musulmanes tenían vedado el acceso a puestos de responsabilidad administrativa, política y religiosa.

10 Para esto, se crean estatutos de limpieza de sangre que buscan el impedimento al ascenso social de los nuevos cristianos perpetuando así el sistema de castas medieval. En 1449, la Sentencia-Estatuto del cabildo de Toledo, primer estatuto de limpieza de sangre, impedía a los conversos ejercer cargos públicos en la jurisdicción de la ciudad. Véase Henry Kamen, Spain's road to Empire: The making of a world power 1492-1763, Penguin, London, 2002, p. 34. M.S. Hering TorRes, “Limpieza de sangre». ¿Racismo en la edad moderna?”, Tiempos Modernos. Revista electrónica de Historia Moderna, Barcelona, 9 (2003), p. 7, n. 25, ofrece un resumen de la expansión de los estatutos de limpieza de sangre desde 1449 a 1540, año en que se aplican a cargos en la Inquisición. 
rio turco ${ }^{11}$. La estrategia de Mexía en estos capítulos de la Silva de varia lección consiste en la representación de oposiciones binarias que enfrentan simétricamente una legítima genealogía romana a una genealogía espuria: el sacro Imperio romano germánico con el Imperio otomano; al emperador Carlos $\mathrm{V}$ y al emperador Solimán; al cristianismo y al islam; e implícitamente al cristiano viejo y al morisco.

\section{LA RAZÓN IMPERIAL}

Los reinos españoles y sus habitantes no aceptaron inicialmente la política imperial debido a que les afectaba económicamente ${ }^{12}$. Se produjo entonces un choque entre los intereses de una visión multinacional del dominio imperial y los intereses locales hispanos a los que se les pedía colaboración económica. El empuje de la amenaza imperial turca en el Mediterráneo oriental y en Europa central sólo podría ser confrontado con un poder imperial. Para ello, era necesaria la colaboración de todos los territorios del Imperio y sus aliados ${ }^{13}$. Si los castellanos habían estado dispuestos a financiar campañas contra los turcos cuando amenazaban intereses cercanos, como en 1527, no lo estuvieron tanto en 1538 cuando asediaban Viena y los territorios imperia-

11 La temida alianza entre los moriscos y los turcos era más un deseo irrealizado de los propios moriscos que una intención real del Imperio otomano. Existe constancia de la petición de los musulmanes granadinos de ayuda a Estambul ante las presiones de la Corona, como es el caso de la casida posiblemente escrita en 1501. Véase James T. Monroe, "A curious morisco appeal to the ottoman Empire", ALAn, 21 (1966), p. 283. En 1570, durante la rebelión de las Alpujarras hubo ayuda turca, pero ínfima y sin un compromiso marcado. Como explica H. KAMEN, durante este conflicto se tiene constancia de que unos 4000 turcos engrosaron las filas moriscas; sin embargo, el Imperio turco, pese a los deseos de los moriscos, nunca dio apoyo relevante a los moriscos españoles frente a las presiones de la corona (op. cit., p. 182).

12 Carlos Javier de Carlos Morales explica la presión fiscal que sobre Castilla impuso el emperador y las dificultades que éste encaró ante las cortes de este reino, en "Castilla y el sostenimiento financiero del imperio de Carlos V”, La Corte de Carlos V, ed. J. Martínez Millán, Sociedad Estatal para la Conmemoración de los Centenarios de Felipe II y Carlos V, Madrid, 2000, t. 2, p. 79.

${ }^{13}$ Véase John H. Elliott, Imperial Spain 1469-1716, Martin's, New York, 1964, p. 169. 
les centroeuropeos ${ }^{14}$. Para convencer de la realidad del Imperio turco como un enemigo común a todos, estos capítulos de Silva de varia lección, obra además dedicada al emperador, aportaron su colaboración.

En el capítulo de su libro, en el que trata de la historia y magnificencia de Constantinopla, Mexía introdujo, a propósito de su caída, una digresión de dos capítulos más que se relacionan tangencialmente con esta ciudad en una manera que pretendía acercar a la sensibilidad hispana la cuestión del peligro turco; peligro que, aunque a veces se acercaba a intereses ibéricos, sobre todo afectaba el comercio de los aliados del imperio en el Mediterráneo oriental ${ }^{15}$. Esta digresión trata, en primer lugar, de la historia del Imperio otomano, que asedió y conquistó Constantinopla en 1453, y, en segundo lugar, de Mahoma, el fundador de la religión oficial de los conquistadores turcos. A pesar del carácter desordenado con que Mexía describe el género de la Silva, los capítulos están inmediata y hábilmente precedidos de otros que tratan de la excelencia militar y de las campañas de conquista: primero el capítulo 8: "Del principio y origen del arte militar y cuáles fueron las gentes y rey que primero salieron a conquistar el señorío ajeno"; y luego dos capítulos más sobre las amazonas y sus conquistas: "Quiénes fueron las belicosísimas amazonas... y cómo conquistaron grandes provincias y ciudades”. Los turcos se

${ }^{14}$ H. Kamen, op. cit., p. 71. Molestaba además que mientras Castilla aportaba fondos, Carlos $\mathrm{V}$ insistía en el carácter multinacional de su imperio (pp. 58-59). Véase la referencia a este asunto en Elliott, op. cit., pp. 159-160. Martínez Millán pone la serie de tapices sobre la toma de Túnez y Goleta encargados al pintor Jan Vermeyen y al tapicero Willem Pannemaker, ambos flamencos, como ejemplo de propaganda imperial para ganarse la simpatía de los reinos hispánicos en cuanto a la alianza contra los enemigos del catolicismo. José Martínez Millán y Manuel Rivero Rodríguez, "Conceptos y cambio de percepción del imperio de Carlos V", en La Corte de Carlos V, ed. J. Martínez Millán, t. 2, p. 41. Aunque la campaña era del máximo interés para Italia, la corte imperial quiso enfatizar la participación hispana en los acontecimientos. Las crónicas de las campañas se encargaron a escritores españoles y las inscripciones que aparecen en los tapices flamencos se escribieron en castellano en vez de en latín.

${ }^{15}$ Ya durante el reinado de Fernando el Católico, había habido enfrentamientos con los turcos por los intereses italianos al sur y al oriente del Mediterráneo (KAMEN, op. cit., pp. 24-25), intereses que eran de la incumbencia de la Corona de Aragón. Cuando se propone la campaña de Túnez, que era también de interés para los aliados italianos, la emperatriz regente abogó sin éxito por una campaña contra Argel, de mayor interés para los reinos españoles (ibid., p. 72). 
encuentran así enmarcados en el contexto de adversarios poderosos y temibles que buscan extenderse. La idea es que un imperio unido puede hacerle frente. Se puede hablar de una campaña que convence de la utilidad de la cooperación entre los territorios del Imperio, basándose en la concepción multinacional que tenía Carlos V de su herencia ${ }^{16}$, frente a las reticencias localistas.

A pesar de su particular obsesión por la veracidad del historiador, Mexía manipula estas narraciones históricas en torno a la ciudad del Asia menor para construir una representación del Imperio otomano y su rivalidad con el Imperio de Carlos V como un conflicto antagónico entre cristianismo e islam; entre oriente y occidente; como una cruzada que habría de traer a la mente del lector hispano la lucha medieval ibérica de la Reconquista recién clausurada por los abuelos del emperador. La idea mantenida por los humanistas españoles de una continuidad del pasado romano de España en su período godo, que fue interrumpida por la invasión islámica de 711, se hace casar con el recuperacionismo clásico del Imperio centroeuropeo de Carlos V. El paréntesis islámico, entendido a posteriori como obstáculo de las aspiraciones religiosas y culturales de la España medieval, se equipara con la rivalidad del Imperio turco con el Sacro Imperio romano germánico, liderado por Carlos V. El hecho de que la realidad del fin de la Reconquista no hubiese significado el fin de la presencia islámica en la Península ibérica, puesto que los antiguos musulmanes pudieron permanecer una vez convertidos al cristianismo, presentaba un problema de convivencia que sería acentuado, intencionalmente o no, por caracterizaciones del islam como la que hará Mexía. La descripción del islam, la historia de sus orígenes y de su fundador que se introduce en estos capítulos sobre el turco y su peligro para la cristiandad implicarían en la práctica la imposibilidad de la integración de los descendientes de los musulmanes españoles en la sociedad cristiana hispánica. Lo que se desprende de estos capítulos, incluidos en la obra más exitosa del humanista sevillano, es que la naturaleza del musulmán, o la del que ha sido musulmán, es tal que hace a estas personas moralmente irrecuperables para la fe y la sociedad cristiana.

El mensaje de la obra de Mexía, que apoyaba la política imperial de Carlos V en cuanto a la necesidad de la unidad de la cristiandad en la lucha contra los turcos, pudo tener el efecto deseado a la hora de convencer a los súbditos hispanos de la con- 
veniencia de apoyar la política imperial: que la política imperial es también, o debe ser, política española ${ }^{17}$. Sin embargo, como se verá, el énfasis en la diferencia del seguidor del islam y su corrupción original pudo avivar el fuego de la intolerancia étnica. Tal intolerancia propició políticas hostiles hacia las prácticas culturales moriscas remanentes, como la Pragmática Sanción de Felipe II en 1567, que provocarían el levantamiento de los moriscos granadinos contra la Corona en la guerra de las Alpujarras (1568-1571).

\section{LA OCGIDENTALIZACIÓN DE ESPAÑA Y LA HISPANIZACIÓN DEL IMPERIO}

La apariencia oriental de la sociedad y cultura peninsular era contemplada de manera incómoda por los seguidores de la nueva dinastía, cuyas señas de identidad eran el Imperio romano y la herencia germánica ${ }^{18}$. Importantes miembros de la corte itinerante de Carlos V consiguieron vencer la resistencia popular contra la alteración de monumentos de la España musulmana, como es el caso de la mezquita de Córdoba, para re-contextualizarlos en las líneas narrativas del Imperio neo-romano ${ }^{19}$. Del mismo modo que la cultura material hispana habría de occidentalizarse, su cultura inmaterial tendría que recuperar sus raíces latinas.

La obra de Mexía encaja dentro de estos proyectos que buscan la redirección cultural de los reinos españoles a sus orígenes latinos y a su alejamiento de la influencia semítica. El motivo de la composición de Silva de varia lección, según dice el autor, es la de trasladar al castellano toda la sabiduría encerrada en los libros latinos que el autor había leído para que sus compatriotas pudiesen tener acceso a esos conocimientos vedados por la barrera del idioma. El receptor al que se dirige esta obra no es el inte-

17 Carlos V consiguió hacer que muchos castellanos identificaran a su país con la cruzada contra el turco y los herejes. Se planteaba como continuación de la tradición de cruzada de Castilla durante la Reconquista (ElliotT, op. cit., p. 169).

${ }_{18}$ Véase YATES, op. cit., pp. 3-5.

19 Alonso Manrique de Lara, hombre cercanísimo al emperador y a los ideólogos de la revitalización del Imperio, en su puesto como obispo de Córdoba (1516-1523) tomó como misión propia, enfrentándose a una beligerante oposición local, la alteración de la mezquita mayor de la ciudad para incluir dentro de ella una catedral renacentista; véase Miguel SALCEdo Hierro, La mezquita, catedral de Córdoba, Cajasur, Córdoba, 2000, pp. 433-434. 
lectual de formación humanista, sino un amplio público lector surgido de la explosión editorial que trajo consigo la imprenta; un público que no tiene a la mano la vastedad de libros que compendian el conocimiento que Mexía brinda; público que no tiene el tiempo para dedicarse al estudio, ni entiende latín, la lengua en que la mayoría de sus fuentes está escrita. Así lo explica el propio autor en el Prohemio de su Silva:

Preciándome de la lengua que aprendí de mis padres como de la que me mostraron mis preceptores, quise dar estas vigilias a los que no entienden los libros latinos, y ellos principalmente quiero que me agradezcan este trabajo pues son los más y los que más necesidad y deseo suelen tener de saber estas cosas. Porque yo cierto he procurado hablar de materias que no fuesen muy comunes, ni anduviesen por el vulgo, o que ellas en sí fuesen grandes y provechosas, a lo menos a mi juicio ${ }^{20}$.

Las palabras de Mexía muestran, como ha notado Asunción Rallo, una intención de nacionalización de la cultura clásica en el contexto español ${ }^{21}$. En el mismo Prólogo de la Silva, dirigido al emperador, Mexía encuadra su dedicatoria de la obra dentro de la tradición que tenían los intelectuales de someterse al poder y lo hace mediante una serie de ejemplos extraídos de la relación entre autores clásicos y emperadores romanos ${ }^{22}$. Además, escribe en castellano para reivindicar la validez de la alta cultura en su lengua vernácula y de este idioma como vehículo apropiado para la difusión del conocimiento de la antigüedad:

Y pues la lengua castellana no tiene, si bien se considera, por qué reconozca ventaja a otra ninguna, no sé por qué no osaremos en ella tomar las invenciones que en las otras y tractar materias grandes, como los italianos y otras naciones lo hazen en las suyas, pues no faltan en España agudos y altos ingenios ${ }^{23}$.

Mexía, como humanista, quiere hispanizar la antigüedad y afianzar el vínculo cultural entre España y el Imperio romano.

20 P. Mexía, Silva, pp. 163-164.

21 Asunción Rallo Gruss, "El sevillano Pedro Mexía, historiador de Carlos V", en Actas del I congreso de historia de Andalucía. T. 2: Andalucía moderna (siglos XVI-XVII), Publicaciones del Monte de Piedad de Córdoba, Córdoba, 1978, p. 308.

22 P. Mexía, Silva, pp. 154-156.

23 Ibid., pp. 162-163. 
A su vez, el nuevo Imperio en manos de Carlos V también debía ser hispanizado. A pesar de que Carlos V era un rey español, los reinos españoles no ven su Imperio como algo propio. Es, más bien, un obstáculo que mantiene a los súbditos españoles separados físicamente de un rey obligado a pasar gran parte de su vida en el exterior defendiendo los intereses de sus otros domi$\operatorname{nios}^{24}$. Así pues, la relevancia hispana del imperio ha de manifestarse con determinados gestos que resultan en la creación de productos culturales que representan esa conexión. Como recuerda Richard Kagan, el momento del nombramiento del propio Mexía como cronista imperial en lengua española no se elige al azar, sino que formó parte de una gran campaña propagandística lanzada a la oportunidad de la victoria contra la liga protestante en Mühlberg, para lo cual se encargaron el famoso retrato ecuestre de Tiziano, la escultura de Leoni del emperador venciendo al furor, y la ya mencionada serie de tapices de la conquista de Túnez con sus textos en castellano ${ }^{25}$.

El proyecto de Mexía de establecer un puente, entre la antigua romanidad de España y su presente, que se advierte en la Sil$v a$, es una constante en la obra del humanista sevillano y se continúa en su siguiente trabajo, Historia imperial y cesárea (1545). Tal pasado debería servir de sustento a la legitimidad del Imperio y del papel de España en el esquema histórico del poder imperial. Como apunta Rallo, Historia imperial y cesárea "ofrece una cadena continua de emperadores cuya culminación sería precisamente el rey español"26. Mexía presentaba las actuaciones imperialistas de Carlos, cuya autoridad emanaba de una herencia legítima, como ligadas a los intereses de los reinos españoles, cuyos habitantes serían los beneficiarios de su propia obra; en sus palabras, para un "público provecho de mi patria y nación" (Historia, p. 3r $\mathrm{r}^{\circ}$.) Por medio del reconocimiento de este vínculo entre España y el mundo antiguo, el lector debería entender su propia relación con el proyecto imperial. Al presentársele el caso del problema turco, el lector también podría identificar la historia de su comunidad con la historia de Constantinopla, originalmente romana y posteriormente conquistada por el islam.

${ }^{24}$ De los 40 años que duró el reinado de Carlos V, sólo 16 los pasó en España (Elliott, op. cit., p. 164).

25 Richard Kagan, op. cit., p. 82.

${ }^{26}$ A. Rallo Gruss, art. cit., p. 311. 
Conviene recordar aquí que la alineación de Mexía con las políticas imperiales no es casual, sino que responde a intereses concretos del autor, independientemente de que, como seguidor de otros humanistas cercanos al emperador, su ideología sea sinceramente afín a estas propuestas. Mexía quería a toda costa agradar al emperador, pues tenía en la mira el codiciado puesto de cronista oficial del Imperio en lengua castellana que estaba vacante después de la muerte de fray Antonio de Guevara. Comenzando con la Silva, Mexía dedica su proyecto al emperador y su realización posterior, la Historia imperial y cesárea, era un ofrecimiento directo para tal puesto, para el cual sería finalmente nombrado en $1548^{27}$. Como recuerda Kagan, en esta última obra Mexía adula abiertamente al emperador agradeciéndole ser el artífice del traslado del imperio de Alemania a España ${ }^{28}$, y cierra la obra abogando por el merecimiento de Carlos V de su propia historia, labor para la que se confiesa incapaz. Kagan apunta la falsa modestia del escritor que, para el momento que fue nombrado cronista del emperador en 1548, ya llevaba tiempo trabajando en la Historia del emperador Carlos $V$, que dejaría inconclusa ${ }^{29}$.

A esta intención hispanizadora de los asuntos políticos imperiales se pueden asociar estos dos capítulos de la Silva de Mexía. El emperador se había comprometido con el Papa a defender los tratados del quinto Concilio de Letrán, entre los que se encuentran reducir las herejías que amenazaban la unidad del cristianismo y hacer la guerra al poderoso turco ${ }^{30}$. Aparte de esta defensa de la fe, Carlos V debe defender sus dominios imperiales, pues el Imperio turco llegó a las mismas puertas de Viena en 1529 y asoló los dominios del Imperio húngaro en los Balcanes. No obstante, los reinos españoles no parecen creer que esta lucha sea un asunto de su incumbencia. Las Cortes aragonesas, que en 1510 en Monzón financiaron la campaña de Fernando, el abuelo de Carlos, contra Túnez (campaña presentada como prolongación de la Reconquista), rechazarían los subsidios de cruzada solicitados por Carlos V en Zaragoza en $1518^{31}$. En las Cortes de Valladolid

27 Véase Antonio Castro, ed. cit., p. 146, n. 8.

28 R. KaGan, op. cit., p. 81.

29 Ibid., p. 82.

30 José Antonio Maravall, Carlos V y el pensamiento político del Renacimiento, Instituto de Estudios Políticos, Madrid, 1960, p. 61.

31 Albert Mas, "Les turcs dans la littérature documentaire en Espagne avan le $\mathrm{XvI}^{\mathrm{e}}$ siècle”, Hommage des hispanistes français à Noël Salomon, Editorial Laia, Barcelona, 1979, p. 571. 
del mismo año, los procuradores se opusieron a tal cruzada por considerarla demasiado lejana y ajena a los intereses españoles, y se reducirían a la protección del cercano norte de África ${ }^{32}$. Los españoles seguían considerando a los turcos como asunto que atañía más a las posesiones imperiales europeas que a sus reinos.

Para convencer a los reinos hispánicos de la necesidad y justicia de su ayuda, la propaganda imperial tuvo que vender una imagen del Imperio turco como encarnación del islam, y una narrativa en la que el pasado de la Reconquista española y la Cruzada contra el Imperio turco fueran equiparables. Se desataba así una campaña antiturca que, por un lado, difundía los horrores de los que era capaz el Imperio otomano y que, por otro, creaba una genealogía de origen ínfimo y despreciable para sus dirigentes. Muchos autores llegaron a prescindir de fuentes fidedignas y positivas existentes para basarse en las obras más sensacionalistas que convinieran al caso $^{33}$.

\section{CONSTANTINOPLA ENTRE DOS IMPERIOS}

Para acercar a la sensibilidad hispana el problema del Imperio con los turcos, la obra de Mexía sigue líneas que buscan conmover el espíritu del fiel cristiano y encuadrar su historia dentro de los parámetros de la obsesión hispánica por la genealogía personal y nacional. Así pues, la narración de Mexía comienza por establecer el origen romano y cristiano de la ciudad del Bósforo. La introducción presenta un acercamiento de lo exótico a lo próximo, de lo desconocido a lo familiar, de lo extraño a lo propio, que se establece desde el primer párrafo del capítulo:

Después de la ciudad de Roma, ninguna ciudad ay ni hubo en el mundo que en tanto poder y honrra se aya visto como la ciudad de Constantinopla... fue silla y cabeça del Imperio mucho tiempo. En ella hubo concilios generales, [donde] fueron destruydas y extirpadas grandes heregías (Silva, pp. 262-263).

La proximidad que esta introducción muestra es, pues, genealógica, cultural y religiosa, pero también geográfica: "El asiento y lugar desta ciudad es [en] nuestra Europa" (Silva, p. 263). Se apunta así que Constantinopla no les pertenece a ellos, sino a nosotros.

32 J.A. Maravall, op. cit., p. 89.

33 A. MAs, op. cit., p. 575. 
La conexión romana y la centralidad para la historia del cristianismo de la antigua Bizancio se continúan con la referencia al traslado de la capital del Imperio a este lugar en el año 330. El artífice de la mudanza de Roma a Bizancio de "la silla imperial y principal assiento de los emperadores", el emperador Constantino, encuentra el reconocimiento para Mexía no en el hecho de esta revolucionaria acción, sino en el hecho de que éste era "hijo de Elena, la que halló el madero de la sancta cruz de Jesuchristo" (Silva, p. 268). Siendo el lector presumiblemente un súbdito cristiano del emperador Carlos V, debería sentir como propia la pérdida de tan señalada plaza, sobre todo después de conocer esta historia romana y cristiana a la que Mexía apunta con insistencia.

$\mathrm{Al}$ mismo tiempo que el proceso de acercamiento al lector hispano de la realidad cultural e histórica de la ciudad representada por Mexía, se produce también el de alejamiento y enemistad de los responsables de la pérdida de Constantinopla para la órbita de influencia del Imperio romano y la cristiandad. La descripción de la conquista turca en 1453, que el autor sevillano contextualiza en el marco histórico del sacro Imperio romano germánico al dar como referencia de este acontecimiento el reinado del sacro emperador del momento Federico III $^{34}$, se detiene especialmente en la barbarie de un conquistador que no respeta ni siquiera la majestad de la dignidad imperial:

Entrados, pues, los turcos en la ciudad, ningún género de crueldad se pudo ymaginar que en los moradores de ella no se haya executado. Todos los del linaje del emperador, hombres y mujeres, fueron metidos a cuchillo; y casi lo mismo en todos los del pueblo, salvo los que quisieron guardar para su servicio (Silva, p. 274).

Dando pruebas, según Mexía, del origen diabólico del Imperio turco, el proceso de extrañamiento del objeto de la narración, con cuyas representaciones se busca propiciar el rechazo del lector, culmina con el relato de un atentado quizás más ofensivo debido a que es un acto sacrílego y blasfemo:

Y no paró en los hombres el atrevimiento desta cruel y diabólica gente; que, tomando la ymagen de Jesuchristo, nuestro Redemptor, la pusieron y crucificaron en una cruz, y enlodándola y ensuziándola, hizieron y representaron otra vez la Passión; y pusie-

34 "siendo emperador de Roma Federico, tercero deste nombre" (Silva, p. 272). 
ron un título en lo alto de la cruz, que dezía: "Éste es el Dios de los christianos", con otras muchas injurias y blasfemias (Silva, p. 275).

Las vejaciones rituales de los símbolos del cristianismo descritas por Mexía parecen reproducir los libelos de sangre incitadores de odio y violencia que tantos pogromos contra judíos habían desatado en Europa en los siglos anteriores.

\section{EL IMPERIO TURCO COMO ANTI-IMPERIO}

Con una visión providencialista de la historia, Mexía atribuye el auge del Imperio otomano a un castigo de Dios ante la degeneración de los emperadores que perdieron Constantinopla: "Por pecados y cobardía de los christianos emperadores de aquellos tiempos, fue esta pestilencia estendiéndose por el mundo" (Silva, p. 286 $)^{35}$. Poco después repite la idea, haciendo responsable a toda la cristiandad corrompida: "[El potentíssimo reyno de los turcos...] ha venido por permissión y azote de Dios, para castigar y emendar el pueblo christiano... assí ha permitido y permite, por nuestros pecados, que el reyno turco fuesse en augmento [y] se estendiesse tanto, para temor, pena y castigo de nuestro descuydo [y] culpas" (Silva, p. 293) ${ }^{36}$.

Frente a ellos, el autor sevillano erige la imagen de un Carlos V como paladín de la fe verdadera que, mandado por Dios, tiene como misión salvar a la cristiandad de los errores del pasado. El ejemplar Carlos V se representa poniendo en peligro su propia vida en las campañas contra el empuje turco en las batallas de Austria y Hungría en 1529: "avemos seydo librados, después del favor de Dios, por la diligencia y cuydado del invictíssimo emperador Carlos, quinto de este nombre, rey de España, señor nuestro" (Silva, p. 286). Siguiendo las tesis de José Antonio Maravall ${ }^{37}$

35 Estrategias similares se usaron para explicar la invasión islámica de España en 711. Las dos leyendas populares de la caída del rey Rodrigo tienen como centro el pecado del monarca. En una, la desobediencia divina al abrir la torre de Hércules en Toledo; la otra, la lujuria que le llevó a la violación de la Cava Florinda.

${ }^{36}$ En Historia imperial y cesárea, Mexía se detiene a culpar a la impiedad del emperador de oriente, Constantino V, la aparición de los turcos (Martin Nuncio, Amberes, 1561, pp. 210-211).

37 J.A. Maravall, op. cit. 
y Ramón Menéndez Pidal ${ }^{38}$, Antonio Castro dice que la intención de Mexía en estos párrafos es la de recalcar la concepción imperial del monarca en su defensa de la cristiandad ${ }^{39}$. Sin embargo, estas líneas también tienen una intención "españolizadora" de la figura del emperador, en oposición a un enemigo común por su diferencia religiosa: el Imperio turco. Carlos es emperador, pero también rey de España. El enemigo turco es representado como el anti-imperio. La civilización otomana, cuando aparece en la escena histórica, se plantea como el reverso de la civilización latina a la que representa el emperador Carlos. El Imperio otomano es el doble negativo del romano. En la descripción con la que continúa Mexía, lo que es excelso en el caso romano, es ínfimo en el otomano. Tal oposición la manifiesta incluso en los orígenes de los líderes de los dos imperios.

En una España en la que la rivalidad entre las castas resultantes de las conversiones masivas y forzadas de las décadas anteriores dio lugar a que la limpieza de sangre se convirtiera en una preocupación principal, el asunto del linaje de los emperadores otomanos sirve para desprestigiar los orígenes del Imperio turco. El fundador del actual Imperio, Otmán I, es descrito como "de baxo linage y estado" (Silva, p. 298) frente a la ascendencia imperial romana de la que podía presumir Carlos, según expondría luego Mexía en su Historia imperial y cesárea, y más tarde en la introducción a la Historia del emperador Carlos $V^{40}$. La antigüedad de la ascendencia de los Habsburgo, que Mexía cotejaría en su otra obra, se pone en contraste con la novedad de los líderes turcos: "El potentíssimo reyno de los turcos, que el día de oy es tan temido y tan grande, y la familia y linage de los Otomanos, reyes y señores dellos, nuevo es y de muy poca antigüedad" (Silva, p. 292). Después de la enumeración de las fuentes de las que dice que toma la información, Mexía se apresura a desautorizar a aquellas que otorgan a los turcos una ascendencia ligada al prestigio de la antigüedad clásica europea. La misma ascendencia

38 Ramón Menéndez Pidal, La idea imperial de Carlos V, Espasa Calpe, Madrid, 1963.

39 Antonio Castro, ed. cit., p. 290, n. 43.

40 R. KAGAN considera esta última exhibición de la genealogía egregia de Carlos V como ejemplo de la característica aduladora del humanista sevillano que le granjearía el codiciado puesto de cronista. Contrapone su caso al del cronista imperial en lengua latina, Juan Ginés de Sepúlveda, que no estaba dispuesto a comprometer su concepto humanista de verdad histórica (op. cit., p. 83). 
troyana que los Habsburgo reclamaban ${ }^{41}$ y que daba al emperador Carlos legitimidad para reinar es tajantemente negada a los turcos: "Y los que piensan y han escrito que [los turcos] descienden de los troyanos, hanse engañado, paresciéndoles que, porque los teucros señorearon Troya y fueron así llamados, que los turcos tuviessen origen dellos" (Silva, p. 295) ${ }^{42}$. Sin embargo, en cuanto se trata de la genealogía de los Habsburgo, en el capítulo sobre el emperador Rodolfo I en su Historia imperial no tiene reparo en citar el fabuloso árbol genealógico creado por Johannes Stabius para Maximiliano I, abuelo del emperador, que no sólo enlaza a los Habsburgo con los emperadores romanos y los héroes troyanos, sino también con los personajes de la Biblia e, incluso, con los dioses de la antigüedad clásica: "hasta producir al mayor monarca y más excelente de todos, el inuictíssimo Emperador don Carlos quinto deste nombre señor y rey nuestro, que por línea masculina de padre a hijo, viene y desciende deste grande Rodulpho"43.

La exposición de la genealogía dudosa de los emperadores turcos culmina con el reinado del emperador contemporáneo al escritor, Solimán el Magnífico: "Coronado el mismo día que fue coronado en Equisgrán el emperador, nuestro señor, ordenado así y dado por Dios para remedio y amparo de la christiandad contra el grande poder de tan sobervio y ambicioso tirano, como la experiencia lo ha mostrado" (Silva, p. 324). Mexía construye el Imperio otomano como el reverso oscuro del sacro Imperio romano liderado por el rey español. Solimán es, en efecto, representado como el anti-emperador, cuya llegada al trono coincide providencialmente con la del propio Carlos V.

\section{LOS TURCOS, MAHOMA Y EL ISLAM}

A la genealogía ínfima de los emperadores turcos y su civilización, Mexía une el principal indicio de la iniquidad e ilegitimidad de su poder, que es su adhesión a la fe musulmana: "[Los scitas o turcas] como hombres sin fe y bárbaros, rescibieron la

${ }^{41}$ MARIE TANner dedica su libro The last dencendant of Aeneas a examinar la representación de esta supuesta ascendencia troyana de los Habsburgo como herramienta legitimadora.

42 Esta idea se repite en términos casi idénticos en Historia imperial y cesárea, p. $228 \mathrm{v}^{\circ}$.

43 Ibid., p. $309 \mathrm{v}^{\circ}$. 
malvada secta de Mahoma, con que toparon primero y que más conforme a sus malas costumbres les paresció" (Silva, p. 291). Según explica Mexía a sus lectores, tal profesión de fe no se debe a una convicción religiosa, sino a la razón perversa de ser una religión que permite la relajación de costumbres, que conviene al carácter vicioso con que el autor describe esta cultura.

El establecimiento de esta conexión del Imperio otomano con el islam sirve a Mexía de transición para introducir su versión de la vida de Mahoma. Tal mudanza le sirve también de maniobra política para la defensa del Imperio, pues conecta al turco, que se quiere hacer ver como peligro real para España, con el posible enemigo interior, los moriscos, cuya representación negativa se fraguaba en esos momentos ${ }^{44}$. Mexía se preocupa especialmente por poner en claro la ilegitimidad del islam como religión verdadera o respetable y la presenta como obra diabólica y malvada. Aunque, en términos generales, Mexía ofrece un compendio de las fuentes medievales de refutación del islam, es particular suyo la importancia que concede a la genealogía espuria de Mahoma y del carácter vicioso de sus primeros seguidores, tema alrededor del cual parece articular su argumento. Como hizo con la representación del Imperio turco y sus líderes, recurre de nuevo al examen del linaje para establecer la ilegitimidad. Así pues, la genealogía del fundador del islam le sirve para mostrar los orígenes indeseables del profeta musulmán, y la genealogía de la religión fundada por él para revelar sus oscuros orígenes, los cuales conecta con prácticas diabólicas.

Al preguntarse por la ascendencia de Mahoma, Mexía revela que cuenta con varias fuentes que ofrecen información dispar: "Platina dize ser de noble linaje. Bibliotecario y Pomponio Leto (diligentíssimo escriptor, al qual yo sigo en este capítulo, principalmente en el Compendio de la romana historia) y otros escriben que su linaje era baxo y obscuro" (Silva, pp. 276-277). Si bien la información tomada de Bartolomé Platina (1421-1481) y Pomponio Leto (1428-1498) es ajustada, Anastasion Bibliotecario (810878) no parece enjuiciar el origen de Mahoma más allá de decir que es descendiente de Abraham por vía de Ismael ${ }^{45}$. Ante la duda presentada por tales discrepancias, Mexía se decanta por

44 Véase supra, n. 11.

45 Bartolomé Platina, Le Vite De Pontifici, Venecia, 1744, p. 115; Anastasio Bibliotecario, Historia ecclesiástica, Bartolome Javarina, Venecia, 1729, p. 55; Pomponio Leto, Compendio del'historia romana, trad. italiana de Francesco Baldelli, Gabriel Giolito, Venecia, 1549, p. 93. 
la que concede a Mahoma un linaje "baxo y obscuro", aduciendo como razón para su convicción que: "hombre tan malo, no sabiéndolo de cierto, no se debe presumir que venga de buena sangre" (Silva, p. 277). Mexía asume una clasificación de la bondad o malignidad de las personas determinada de acuerdo con la ascendencia familiar para dejar claro después que, de una manera u otra, el origen del fundador del islam es despreciable por su condición pagana: "Su padre, quier que fuesse, noble o villano, él era gentil ydólatra... y no judío ni cristiano”. En cuanto a su madre, aunque reconoce su descendencia directa de Abraham, la señala como de descendencia ilegítima: "por línea de Ysmael, su hijo, avido en Agar, su sierva" (id.) Es vástago de una rama bastarda de los descendientes del profeta hebreo, pues Ismael fue concebido fuera del matrimonio. Esta apreciación del origen del linaje de Mahoma que Mexía da por hecho aparece en la obra de Platina no como afirmación, sino como comentario sobre cómo algunos griegos referían este linaje como insulto ${ }^{46}$.

La condición advenediza del profeta del islam se continúa representando en el relato biográfico siguiendo a las autoridades mencionadas. Cuenta Mexía que, muertos sus padres cuando todavía era niño, fue capturado por beduinos sirios que lo vendieron a un mercader. Al morir este mercader, quien según Mexía "lo crio y tractó como a hijo y no como a esclavo" (Silva, p. 278), Mahoma se casó con su viuda. Así pues, a la acusación de traición de la confianza del benefactor, se añade la insinuación de incesto y el interés económico que tenía Mahoma en esta unión:

En esta sazón murió este mercader, señor suyo, sin dexar hijos algunos, y quedó la biuda muy rica, en edad de cinquenta años; y según hallo escripto en los Anales constantinopolitanos, algunos dizen que era parienta de Mahoma y llamada Ladiga. La cual, contenta de la persona del moço y de su recaudo, y por buena negociación que él tendría tomó por marido al Mahoma y, de pobre [y] siervo, hízolo señor y muy rico (Silva, p. 279).

Si la ascendencia del fundador del islam es cuestionable según Mexía, los orígenes de la religión no son menos ilegítimos. Como una versión adulterada de un cristianismo heterodoxo, Mexía conecta los inicios de la religión de Mahoma con la herejía cristiana y la magia diabólica, representadas en la figura del que considera su cómplice, el monje hereje Sergio: "Hombre

46 Op. cit., p. 115. 
muy astuto, de malas mañas y que venía huyendo de Constantinopla por herege. Acertó a tener grande conversación y amistad con Mahoma, que ya tenía altos los pensamientos, pero malos, y era muy agudo mágico" (id.) La nueva secta que surge de la colaboración de dos personas, cuyo carácter ha sido puesto en cuestión constantemente por el humanista sevillano, se presenta como una compilación de herejías: "Y en muchas cosas concordó con los erejes de aquel tiempo, por tenerlos favorables: con los sabélicos, negó la trinidad; con Macedonio, ereje, negó el Espíritu Santo ser Dios; con los nicolaítas, aprovó la muchedumbre de las mujeres" (Silva, p. 281). La acomodación de todas estas herejías como germen del islam sirve para presentarlo como tocado desde el principio por la perversión moral "permitiendo en su falsa doctrina vicios y carnalidades y libertades" (id.). Así, el escritor explica que la motivación para la creación de la nueva religión es la de atraerse a todos aquellos que buscaban dar libremente rienda suelta a sus vicios: "A los principios llegáronse a él los livianos y de poco juycio... luego, los malos, amigos de la libertad y viciosos" (Silva, p. 285). En estas últimas acusaciones, Mexía sigue fielmente, aunque no lo revela entre sus fuentes, a Polidoro Virgilio, como ha señalado Serrano Cueto ${ }^{47}$. El mismo autor, sin embargo, es de los que consideran a Mahoma hijo de un hombre de origen noble, si bien "adorador de espíritus malignos" y de madre hebrea ${ }^{48}$, opción que es descartada por Mexía en el razonamiento arriba expuesto.

Mexía extiende la iniquidad de los primeros seguidores del islam a la falta de sinceridad en la propia creencia en las doctrinas de Mahoma y a la traición al propio líder: "y en esta maldita prosperidad, teniéndolo todos por mensagero de Dios, secretamente le dieron los suyos ponçoña (en lo cual se verá cómo más le seguían por los vicios y libertad, que por tener por cierta su doctrina)" (Silva, p. 285). Los seguidores de Mahoma quedan marcados por su carácter insincero y traidor. Sus motivos para abrazar la nueva religión se reducen a la búsqueda de una vida de vicio en libertad.

47 Antonio Serrano Cueto, "Pervivencia del De rerum inventoribus de Polidoro Virgilio en la literatura española: la Silva de Pedro Mexía”, en Humanismo y pervivencia del mundo clásico, eds. J.M. Maestre et al., Instituto de Estudios Humanísticos, Alcañiz-Madrid, 2009, t. 3, pp. 1542-1543.

48 Polidoro Virgilio, De gli inventori delle cose, Domenico Gromi, Brescia, 1680 , p. 351. 
Tras esta construcción tan genealógicamente determinada de los orígenes del islam y de sus seguidores, cabe preguntarse dentro del contexto social de la España de Mexía qué lugar cabría para confiar en los considerados descendientes de este pueblo en España: los moriscos; qué lugar quedaría para confiar en la sinceridad de la conversión al cristianismo de este grupo si, según se deduce de la información aportada por Mexía, por tantas generaciones habían sido tocados por el mal y vivido en el vicio. Si la genealogía determina con tanta fuerza el carácter de las culturas, los gobiernos y el individuo ¿cómo sería posible la integración sincera de los antiguos seguidores del islam en el proyecto imperial cristiano de los Habsburgo?

\section{LOS MORISCOS}

Las políticas de homogeneización religiosa, llevadas a cabo por los últimos Trastámaras a finales del siglo xv y principios del Xvi en los reinos hispánicos, se vieron reforzadas con la llegada de la dinastía austríaca y sus nuevas políticas de homogeneización, en este caso de índole cultural, impulsadas por la ideología del sacro Imperio romano germánico. Las formas de propaganda que buscaban el acercamiento de la opinión ibérica a los objetivos de la misión imperial, centrados en la promesa de protección y defensa del catolicismo, no hicieron sino acentuar la brecha de la diferenciación en la península entre los cristianos viejos y los descendientes de los practicantes de otros credos. Se erosionaba, así, la diversidad cultural que había sido la norma en los reinos hispánicos de la Edad Media. El morisco, descendiente cristianizado de los habitantes musulmanes de la Península ibérica, todavía parecía contaminado de su antigua fe después de una conversión que no convencía a la jerarquía eclesiástica. La conexión diabólica del islam y sus primeros seguidores, a la que se apuntaba en la obra de Mexía, sería suficiente para sospechar de la ortodoxia cristiana del antiguo vecino mudéjar.

Por razones económicas, había un interés por parte de la política imperial en convertir al turco en un peligro real en la mente del español, y Mexía era un aliado que buscaba promover las ideas del Imperio. Estas razones son los subsidios que el emperador quiere conseguir de los reinos peninsulares para sus campañas contra los turcos en las zonas amenazadas de su 
Imperio $^{49}$. Para la construcción de este peligro, se emplea la razón religiosa, el motivo de cruzada contra el infiel, como lo fue la Reconquista, de lo que se hace eco Mexía. Es parte del compromiso de Carlos con el Papa tras el Concilio de Letrán $\mathrm{V}$, reflejo de su imagen como miles christianus, y prioridad para conseguir la adhesión de los reinos españoles a la política imperial, pues éstos la ven con resentimiento y como algo ajeno a los intereses españoles.

El énfasis en el compromiso de lucha contra el infiel en los márgenes del Imperio se debió extender entonces al ámbito próximo. Había que hacer públicas, entonces, las señales que demostraran herejía "islamizante" dentro de España; que denunciaran la pertenencia de cualquier vecino a la religión prohibida, a la que se otorgaron visos diabólicos para provocar el terror, pues exteriormente los moriscos eran indiferenciables de los demás vecinos. De acuerdo con Julio Caro Baroja:

Contra lo que pudiera imaginarse, hacia 1550 o 1560 no cabía establecer gran diferencia racial entre la población morisca y la cristiana vieja de muchos pueblos de Granada, Almería y Murcia. La distribución entre unos y otros era de tipo social, no biológico. Se hacía teniendo en cuenta la línea masculina y la religión del padre. Así un cristiano viejo e hidalgo por añadidura, podía ser, y de hecho era con frecuencia, hijo de madre morisca y nieto, también de abuelas moriscas ${ }^{50}$.

La unidad de la cristiandad que pretendía el Imperio de Carlos $\mathrm{V}$ chocaba con la paradoja del componente musulmán de la sociedad española; era una contradicción que había que solventar. En un principio, el morisco no era percibido como peligro, pues una vez conseguido el poder político y tras siglos de convivencia y mezcla étnica no se puede pensar en el morisco como alguien radicalmente diferente. Así pues, la actividad de la Iglesia, que sospecha del morisco porque lo entiende como corrompido por el origen de su estirpe, se movía para revelar esta ame-

49 Viena fue asediada en varias ocasiones por las huestes de Solimán entre 1529 y 1532. Buda quedó bajo el control de los turcos de 1541 hasta 1686. La amenaza turca al Mediterráneo occidental basada en apoyos del norte de África era especialmente real para la zona de influencia italiana. Las costas podían ser atacadas por piratas. Las remesas de cereal de Sicilia se vieron interrumpidas (Elliott, op. cit., p. 168 y H. KAMEN, op. cit., p. 155).

${ }^{50}$ Julio Caro Baroja, Los moriscos del Reino de Granada: ensayo de historia social, Instituto de Estudios Políticos, Madrid, 1957, p. 65. 
naza. De la misma manera que el pueblo español no veía peligro que le afectara en el avance del Imperio turco, para lo cual Mexía se presta como lazarillo, la Iglesia se encarga de destapar el peligro que no ve en el musulmán convertido.

Si la falta de percepción de la diferencia era el caso en las zonas recientemente conquistadas a las que aludía Caro Baroja, cuál no sería el grado de integración racial y cultural en el territorio ocupado siglos atrás ${ }^{51}$. Al final del siglo XVI, la fusión de los dos grupos religiosos llegó a ser tan profunda que los africanos que recibieron a los moriscos expulsados entre 1609 y 1614 quedaban escandalizados de la "cristianización" de estos musulmanes de la misma manera que los europeos se escandalizaban de la islamización de los cristianos españoles ${ }^{52}$. Los líderes musulmanes se quejaban de que sus fieles no recordaran el árabe ni sus obligaciones religiosas si no se redactaban en castellano ${ }^{53}$. Después de la expulsión, los antiguos moriscos españoles tuvieron que ser adoctrinados en la fe del islam en castellano una vez que estuvieron en sus exilios africanos, como cuenta el autor del manuscrito m-2 que Luce López-Baralt recupera en su libro $U n$ Kama Sutra español ${ }^{54}$.

51 La diferencia más notable culturalmente hablando existiría en los territorios del antiguo reino de Granada, cuyas prácticas culturales habían sido permitidas a cambio de impuestos especiales a la Corona. Cuando finalmente se prohíbe de manera tajante la continuación de estas prácticas mediante la pragmática de 1566-1567, la rebelión explota en Granada dando lugar a una guerra que durará de 1568 a 1570. A la derrota del bando morisco siguió la obligatoria dispersión de los moriscos granadinos por toda Castilla para impedir una nueva rebelión multitudinaria y para diluir los lazos que permitieran la salvaguarda de las características culturales propias (ElliotT, op. cit., pp. 238-241).

${ }^{52}$ AnwAR B. CHejne, Islam and the west: The moriscos. A cultural and social history, State University of New York Press, Albany, 1983, p. 123.

${ }^{53}$ Ibid., p. 375. Es el caso del alfaquí de Segovia Içe de Gebir que en 1462 tiene que escribir en castellano unos Mandamientos y devedamientos de la ley y cunna, y el poema aljamiado de Yuçuf que usa formas del mester de clerecía para dar forma a una leyenda musulmana. Véase Francisco MÁrQUez Villanueva, El problema morisco (desde otras laderas), Libertarias, Madrid, 1991, p. 20. Mercedes García Arenal informa que en Cuenca los moriscos extraían información sobre los preceptos de la fe islámica de los escritos antimoriscos en castellano (Inquisición y moriscos. Los procesos del Tribunal de Cuenca, Siglo Veintiuno, Madrid, 1987, p. 161).

${ }^{54}$ Luce López-Baralt, Un Kama Sutra español, Siruela, Madrid, 1992, p. 81. 
La convivencia creada por la falta de diferencia debió ser al principio más o menos tranquila. Según explica Deborah Root: "At the everyday social level the mudejars do not seem to have been recognized as deviants, as those who exist outside" 55 . Contra este roce, contra esta proximidad peligrosa y contaminadora se quería luchar desde la Iglesia. Se intenta hacer cada vez más patente la diferencia entre la comunidad cristiana vieja y la morisca. $\mathrm{Al}$ no ser percibida la diferencia superficial, en el físico o en la persona pública del morisco, se sucedieron una serie de edictos que regulaban la vida privada haciéndola pública ${ }^{56}$, de manera que lo que quedara de prácticas tradicionales que pudiesen parecer "islamizantes" fueran denunciadas. Había que publicar además por qué el morisco es diferente e indeseable, siendo teóricamente un vecino cristiano más.

La aportación de Mexía de su información sobre la vida de Mahoma, sobre sus orígenes impuros, su filiación diabólica y la condición de los que le siguieron y le siguen, se suma a la propaganda que duda sobre la sinceridad de la conversión de estas gentes. Su relación con una forma de vida tocada por el demonio hacía que sus vidas y su estirpe quedaran indeleblemente marcadas de forma negativa. A partir de la apreciación de Mexía acerca del islam como imán de viciosos, se podría entender que cualquiera que hubiera tenido algún contacto con la religión de Mahoma estaba manchado por ese origen herético. El hecho de que hubiesen abrazado en un momento de la historia esta religión se explicó porque ésta respondía a sus necesidades y les permitía vivir en el vicio al que estaban inclinados. Si su adhesión a esta fe se debía a motivos de interés, se deducía que igualmente carecería de sinceridad la adhesión de estas personas al cristianismo.

Si bien muchas de las ideas que Mexía propone vienen dadas de la tradición de la literatura anti-islámica, al verterlas a la lengua

55 D. Root, art. cit., p. 121. De la existencia de esta falta de percepción de la diferencia, tenemos buenos ejemplos en la literatura. En Guzmán de Alfarache, el protagonista se pone de parte de un buñolero morisco censurando la mezquindad del corregidor que lo arruina (F. MárQuez Villanueva, $o p$. cit., p. 24). En el cap. 54 de la Segunda parte del Quijote, Sancho es saludado por un antiguo vecino morisco que se había marchado del país después del decreto de expulsión: “-¡Válame Dios! ¿Qué es lo que veo? ¿Es posible que tengo en mis brazos al mi caro amigo, al mi buen amigo, al mi buen vecino Sancho Panza?" (El ingenioso hidalgo don Quijote de la Mancha, ed. J. Jay Allen, Cátedra, Madrid, 1984, t. 2, p. 432, cursivas mías).

56 D. Root, art. cit., p. 120. 
vernácula se les da una difusión que antes no existía. La amplia difusión de estas ideas, avaladas por las más respetables autoridades del mundo antiguo que Mexía con cuidado selecciona y criba, pudo servir tangencialmente para seguir acrecentando la desconfianza en el vecino morisco y en la sinceridad de su conversión. En los tratados anti-moriscos que defendieron la expulsión ya en el siglo XVII aún se encuentran algunos ecos de las expresiones de Mexía. Así pues, Jaime Bleda, de manera similar a Mexía, rechaza a Bibliotecario como fuente de la nobleza de Mahoma y, casi repitiendo el argumento de Mexía, dice: "que Mahoma nació de sangre vil, y de gente soez... Y así no parece creyble, que entre gente tan bárbara se aya tenido cuenta con tantos grados de genealogía" ${ }^{57}$. De un modo similar, Marcos Guadalajara y Javier reprende a Herman Dalmata, o de Carintia (1100-1160), por haber dado una genealogía de Mahoma en su De generatione Muhamet et nutritura eius "pues para un recuero hizo tan larga genealogía" ${ }^{58}$. Y Aznar Cardona, el más difundido de los polemistas anti-moriscos, reproduce casi literalmente el ninguneo de la estirpe de Mahoma y sus seguidores que hacía Mexía en su Silva y en su Historia imperial cuando evidenciaba que eran descendientes de una rama ilegítima de Abraham, la que llegaba de su unión adúltera con su sirvienta Agar: "Sarracenos, nombre que tomaron por honrarse, deuiendo ser llamados, Agarenos, por la madre Agar, o Ismaelitas, por su padre Ismael" ${ }^{29}$.

La conscientemente herética incompatibilidad de la imagen que presenta la síntesis de autoridades que hace Mexía sobre los seguidores del islam en virtud de su genealogía pudo servir para apuntar a la manifestación de dónde está esa diferencia original entre el morisco y el cristiano viejo que no es apreciable exteriormente. Si la intención primera era la de mover a la opinión de ese amplio público lector que no tenía acceso a estas fuentes escritas en latín y que había surgido al amparo de la impren-

57 Jaime Bleda, Corónica de los moros españoles, Felipe Mey, Valencia, 1618, pp. 4-5.

${ }_{58}$ Marcos Guadalajara y Javier, Memorable expulsión, y justíssimo destierro de los moriscos de España, Nicolás de Assiayn, Pamplona, 1613, p. 33v ${ }^{\circ}$.

59 Pedro Aznar Cardona, Expulsión justificada de los moriscos españoles, Pedro Cabarte, Huesca, 1612, p. 151vº. En Historia, Mexía dice: "aunque verdaderamente se deuieran llamar Agarenos Hismaelitas, porque Mahoma descendía de Abraham por la vía de Agar sierua, y de Hismael su hijo" (p. 194v ); y en la Silva: "no venían de Sarra, mujer de Abraham, para que deviesen ser llamados sarracenos, como ellos se llamaban, sino de Agar la siervam y por ello agarenos" (p. 277). 
ta para que comprendiera y apoyara las políticas imperiales en fronteras lejanas, el efecto cercano habría sido la contribución a las ansiedades de los ibéricos de limpieza de sangre y al fomento de la acentuación de la otredad de este segmento de la sociedad española.

Lucas A. Marchante-Aragón

City University of New York College of Staten Island 
